\title{
Surface Roughness and Material Removal Rate Behaviors of Hard Materials such as Titanium Alloy, Nickel-Based Super Alloy and Tool Steel
}

\author{
Shashi Prakash Dwivedi*, Shailendra Singh Chauhan \\ G. L. Bajaj Institute of Technology \& Management, Greater Noida, Gautam Buddha Nagar, U.P. 201310, India
}

Corresponding Author Email: spdglb@gmail.com

https://doi.org/10.18280/ti-ijes.642-420

Received: 15 March 2020

Accepted: 26 May 2020

\section{Keywords:}

hard materials, Ti-6Al-4V, Inconel-718, tool

steel, MRR, surface roughness

\begin{abstract}
Hard materials like Titanium Alloy (Ti-6Al-4V), Inconel-718 and Tool Steel has always played a challenging role in machining and cutting operations in the industries. In this research-based analysis, comparative study of Titanium Alloy (Ti-6Al-4V), Inconel-718 and Tool Steel has been presented. Four different samples of each material of equal dimensions were taken at different machining parameters. Material removal rate (MRR) and surface roughness were obtained. SEM image with EDAX has been performed. The quantitative results gave basic ideas about the variation of materials behavior of machining which provides a range for selecting parameters of Titanium Alloy (Ti-6Al-4V), Inconel718 and Tool Steel.
\end{abstract}

\section{INTRODUCTION}

Hard material machining is always a challenging area for manufacturing sectors. There are various hard materials utilized in the manufacturing of various parts. Titanium alloy, nickel-based superalloy and tool steel are also very hard metals and used in the various industrial applications [1-4]. Titanium is the ninth most abundant element in earth's crust. It is a lowdensity element whose strength can be increased significantly. The strength can increase by alloying and deformation processes [5-9]. Titanium and its alloy have a very good strength to density property which makes the titanium alloy exceptional use. These properties are mechanical properties, high fatigue strength, biocompatible, erosion and corrosion therefore titanium and its alloy have a large number of applications. Its widely used in aerospace application like an aircraft engine, missiles etc. it is also used in petroleum and chemical production. It has got an important role in food and pharmaceuticals processing. Various sports equipment and power generation types of equipment are made of Titanium and its alloy [10-11].

Inconel-718 is the heat resistant super alloy and extensively used in the manufacturing of component for liquid rockets, part of aircraft, turbine engine, cryogenic tankage etc. [12-15]. Inconel-718 is mainly used because it sustained high resistance to corrosion, mechanical and thermal shock, mechanical and thermal fatigue. Inconel is the member of nickel chromium-based super alloy and are well suited in an extreme environment subjected to pressure and heat. When we heat Inconel material, it forms a thick stable oxide layer protecting the surface from further attack [16-18]. Inconel maintain strength over a wide temperature range, attractive for high temperature and applications. In Inconel, the hightemperature strength is developed by a solid solution. Inconel alloy is used in high-temperature applications like nuclear reactors, gas turbine engine parts etc. The space shuttle used four Income studs to secure the solid rocket boosters. It is also used in the engine manifold. Inconel is used in the automotive industry. Inconel-718 has excellent welding characteristics and post-weld age cracking resistance $[19,20]$.

Tool steel is used in the shaping of other materials. The carbon content in tool steel is lying between $0.5 \%$ and $1.5 \%$. To maintain the quality, tool steel is manufactured under very controlled condition. The existence of carbides in their matrix having an important role in ensuring the quality of tool steel. Mainly, tool steels categorized into six groups: shock-resistant high speed, water hardening, cold work, hot work and special purpose. Tool steels are used for the many industrial applications for example in cutting operations, pressing and coining of metals and other materials [21]. Tool steel contains various elements such as tungsten, molybdenum, cobalt and vanadium to increase the heat resistant and durability of the material. Tool steel is ideal for cutting and drilling. Various tool steel is carbon steel, alloy steel and high-speed steel is capable of being quenched. Tool steels are melted in electric arc furnaces and produced by using certain practices to satisfy particular specification [22]. It has a very special heat treatment characteristics and manufacturing considerations. In comparison tool steel is offers much better performance than tonnage steel. Tool steel is a member of steel that contain dispersed carbides in the hardened steel matrix. For welding purpose, aluminum alloys tool steel is most widely used. Tool steel is necessary materials in industrial fields and are used for cutting tools, dies, mould etc. Tool steel is a hybrid between a cemented carbide and steel [23-25].

Surface roughness is a parameter which indicates the condition of the machined surface. The quality of the surface is defined as the surface roughness. Various methods are available to measure surface roughness. In this work, linear roughness measurement is done experimentally. In linear roughness measurement, a single line on the sample surface measure has been done. Basically surface roughness is measured by the deviation of the normal vector of a real surface from its ideal form. If the deviation is measuring large 
then the surface is found to be rough whereas if the deviation is small the surface is considered as smooth. The roughness of any material determines how an object will interact with its environment.

From the literature, it was observed that very few researchers compared the machining behavior of titanium alloy and nickel-based superalloy with tool steel. Keeping these facts in the mind, in the present investigation, a comparative study of the machining behavior of titanium alloy and nickel-based superalloy with tool steel has been carried out.

\section{MATERIALS AND METHODS}

\subsection{Materials}

In this study, Titanium alloy Ti-6Al-4V, Inconel 718 and Tool steel have taken for the machining operation. Table 1 shows the property of Titanium Alloy (Ti-6Al-4V). Figure 1 (a) shows the machined sample of titanium alloys [1]. Table 2 presents the property of Inconel-718. Figure 1 (b) shows the machined sample of Inconel-718. Table 3 illustrates the property of tool steel. Figure 1 (c) shows the machined sample of tool steel [3-6].

Table 1. Titanium Alloy (Ti-6Al-4V) properties [8-11]

\begin{tabular}{cc}
\hline Density (gm/cm3) & $4.429-4.512$ \\
\hline Young modulus (GPa) & $104-113$ \\
Shear modulus (GPa) & $40-45$ \\
Bulk modulus (Gpa) & $96.8-153$ \\
Poisson's ratio & $0.31-0.37$ \\
Tensile Yield Strength (MPa) & $880-920$ \\
Ultimate Tensile Strength (Mpa) & $900-950$ \\
Hardness Rockwell C & 36 \\
\hline
\end{tabular}
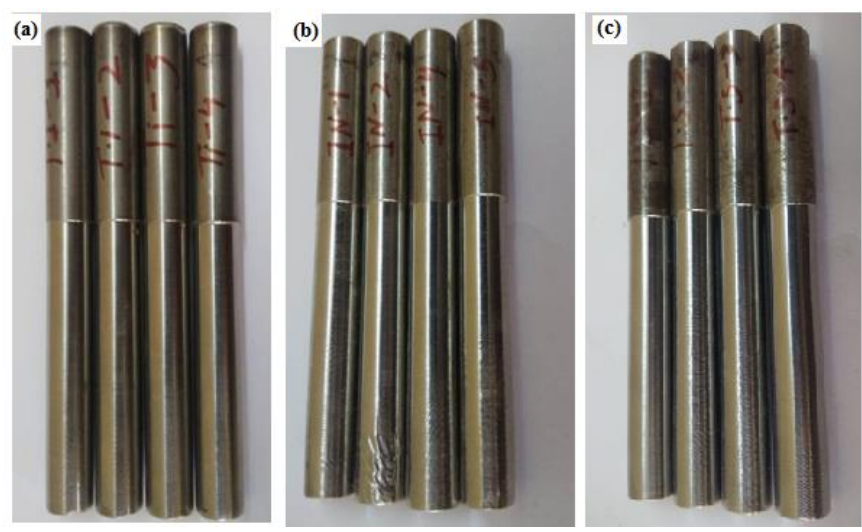

Figure 1. (a) machined sample of titanium alloys, (b) machined sample of Inconel-718, (c) machined sample of tool steel

Table 2. Inconel-718 Properties [12-15]

\begin{tabular}{cc}
\hline Density $(\mathrm{gm} / \mathrm{cm} 3)$ & $8.192-8.22$ \\
\hline Young modulus $(\mathrm{GPa})$ & 200 \\
Shear modulus (GPa) & 77.2 \\
Poisson's ratio & 0.294 \\
Tensile Yield Strength (MPa) & $550-725$ \\
Ultimate Tensile Strength (Mpa) & $965-1035$ \\
\hline
\end{tabular}

Table 3. Tool Steel Properties [20-23]

\begin{tabular}{cc}
\hline Density $(\mathrm{gm} / \mathrm{cm} 3)$ & 8.03 \\
\hline Young modulus $(\mathrm{GPa})$ & \\
Shear modulus $(\mathrm{GPa})$ & 77 \\
Bulk modulus $(\mathrm{Gpa})$ & 140 \\
Poisson's ratio & $0.27-0.30$ \\
Hardness Rockwell C & $61-62$ \\
\hline
\end{tabular}

\subsection{Machining of samples}

Machining of Titanium Alloy (Ti-6Al-4V) on CNC machine was done with the consideration of four important characteristics like strength, thermal conductivity, modulus of elasticity and shear mechanism. Since titanium alloys consist of a mixture of titanium and other chemical elements and have a very high tensile strength and toughness properties even at extreme temperature. During machining operation on the CNC machine, a lot of effort was required for deforming Ti6AI-4V into chips. It was observed that much energy consumed by the spindle into and converted heat. It was also noticed that during the machining operation due to high modulus of elasticity and shearing mechanism characteristics of titanium Alloy sharp with aggressive rake angle and high relief angle were used to avoid tearing and dispersion of the titanium workpiece. As the Ti-6Al-4V has low thermal conductivity so limited cutting speed was used. To protect the tool and workpiece a large volume of coolant at high pressure was required just because of high energy was created during machining of the samples. In order to improve machinability LN2 coolant was used. While machining Ti-6Al-4V the cutting speed was limited to $60 \mathrm{~m} / \mathrm{min}$ because increasing the cutting speed will also reduce the cutting tool life. As the turning of titanium alloy is a little bit difficult therefore carbide tool was used for achieving good surface finish and tool life. After machining, the next sample was introduced with different parameters and the same procedure continues.

\subsection{Surface Roughness and its measurement}

In the present work, the surface roughness of the samples is measured by the contact profilometer. In this method, a profilometer with a diamond stylus is progressed vertically in continuous contact with a sample and then it moved laterally across the sample for a specified distance and specified contact force to measure a small variation in the surface of the sample. The diamond stylus first generates an analogue signal which is further converted into a digital signal. This signal can be stored, analyzed and displayed for precise surface roughness measurement. The radius of the diamond stylus of the profilometer ranges from 20 nanometers to 50 micrometres.

For the target surfaces that have periodic roughness profile estimated parameter from the measured primary profile but when the roughness profile is not periodic, unknown parameters were estimated like average roughness (Ra), Rootmean-square roughness (Rz or RMS) from the measured primary profile. After this visual inspection is used to determine whether the target's surface texture is uniform or different in various locations. When the target surface texture is uniform then judged whether the parameters are within the permissible ranges and if the target surface texture is different in various location then also judged whether the parameter is within the permissible ranges. The testing machine was digital type in which the analogue signal was converted to a digital signal. Twelve different samples identified on which 
roughness testing was to be done. The operator took a sample and placed it on the machine where the automatic stylus moved along the longitudinal axis on the surface of the workpiece. Computer-generated slip with all details ( $\mathrm{Ra}$, Rzetc) and graph are presented in Figures 2 (a), (b) and (c). This procedure was repeated for all the samples.
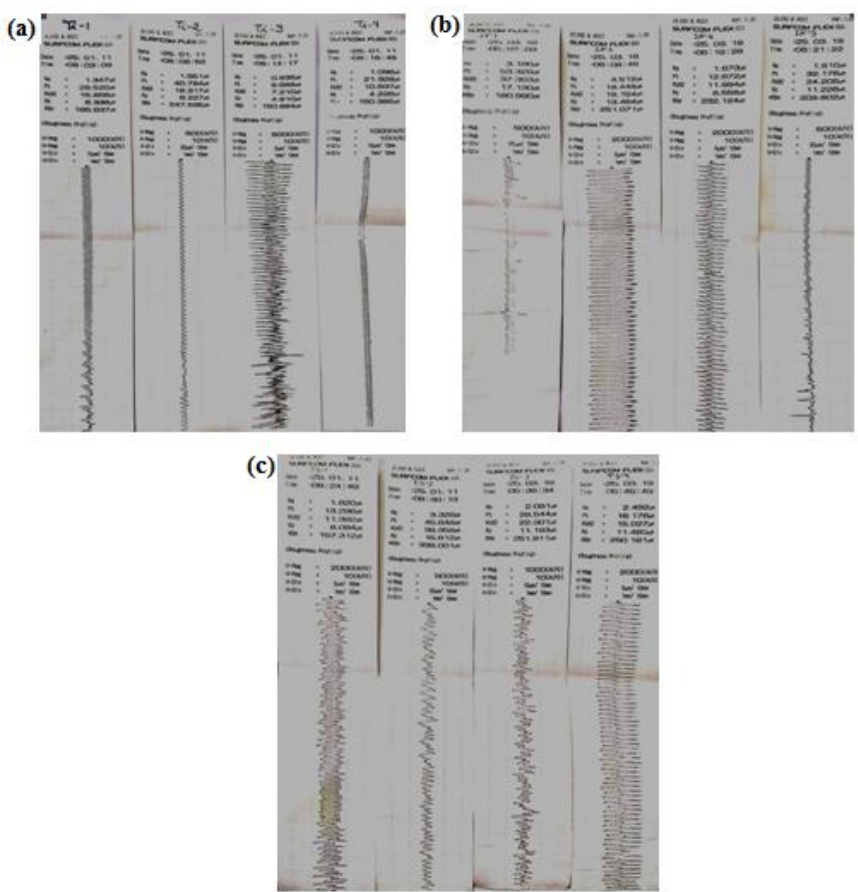

Figure 2. (a) Ti-6Al-4V surface roughness values and graph, (b) Inconel-718 surface roughness values and graph, (c) Tool steel surface roughness values and graph

\section{RESULTS AND DISCUSSION}

\subsection{Machining results of Ti-6Al-4V}

In machining operations, the MRR and surface roughness are an important consideration to measure the quality of the machining and economy. In the first experiment, Ti-6Al-4V was machined and the measured value of MRR and surface roughness are shown in the design matrix in Table 4. Some parameters were fixed in the first step such as cutting speed of $200 \mathrm{rpm}, 0.15 \mathrm{~mm}$ feed and $0.2 \mathrm{~mm}$ depth of cut. Table 4 shows the MRR and surface roughness of Ti-6Al-4V alloy. The operation was held for 17 seconds. The result of MRR was $0.01529 \mathrm{~g} / \mathrm{sec}$ and surface roughness was measured $\mathrm{Ra}=1.347$ micron and $\mathrm{Rz}=6.538$ micrometre. In the second step the machining parameters were changed, the cutting speed was taken $200 \mathrm{rpm}$, feed $0.25 \mathrm{~mm} / \mathrm{rev}$ and $0.04 \mathrm{~mm}$ depth of cut. On these parameters, the operation was performed on Ti-6Al-4v. The time was taken for 12 seconds. The MRR was 0.08583 $\mathrm{g} / \mathrm{sec}$ and surface roughness was $\mathrm{Ra}=1.551$ and $\mathrm{Rz}=8.227$ micrometre. In the third step, the parameters were changed by $300 \mathrm{rpm}$ speed, $0.25 \mathrm{~mm} / \mathrm{rev}$ feed and $0.2 \mathrm{~mm}$ depth of cut. The Ti-6Al-4V was operated; the cutting time was taken for 11 seconds and the MRR was recorded as $0.0218 \mathrm{~g} / \mathrm{sec}$. The surface roughness was found $\mathrm{Ra}=0.835$ micrometre and $\mathrm{Rz}=4.910$ micrometre. In the fourth step, the parameters were changed by $300 \mathrm{rpm}$ speed, $0.15 \mathrm{~mm} / \mathrm{rev}$ feed and $0.4 \mathrm{~mm}$ depth of cut. The cutting time was taken for 12 seconds. The MRR was $0.09307 \mathrm{~g} / \mathrm{sec}$. The surface roughness $\mathrm{Ra}=1.096$ micrometer and $\mathrm{Rz}=4.226$ micrometre. Since, the shear hardening and excessive shear localization occurred due to the phase transformation of the titanium structure therefore, Material strain-hardening capacity will be reduced due to low thermal conductivity. During machining of Ti alloy chip morphology considerably influenced by cutting speed and feed. The material removal rate of Ti-6Al-4V has increased by the increment of speed and feed rate. Whereas, it was observed that the surface roughness has decreased. Figure 3 shows the SEM image and Energy Dispersive X-Ray Analysis (EDAX) Pattern of Ti-6Al-4V at speed $200 \mathrm{rpm}, 0.15 \mathrm{~mm}$ feed and $0.2 \mathrm{~mm}$ depth of cut. Surface roughness trends were observed in the SEM test. At high speed, comparatively fair results were observed.

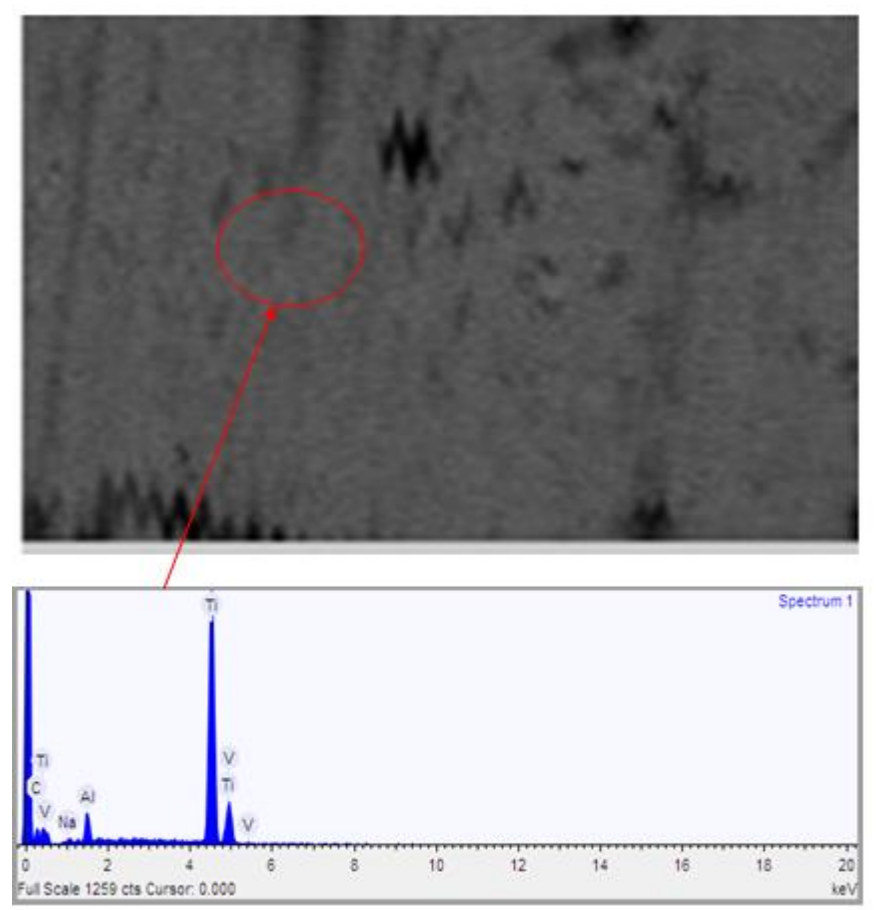

Figure 3. Ti-6Al-4V SEM Image and EDAX Pattern

Table 4. Design matrix Table for Ti-6Al-4V

\begin{tabular}{|c|c|c|c|c|c|c|c|c|c|}
\hline $\begin{array}{l}\text { Serial } \\
\text { No. }\end{array}$ & Speed & Feed & $\begin{array}{l}\text { Depth of } \\
\text { cut }(\mathrm{mm})\end{array}$ & $\begin{array}{l}\text { Weight before } \\
\text { machining }(\mathrm{gm})\end{array}$ & $\begin{array}{l}\text { Weight after } \\
\text { machining } \\
(\mathrm{gm})\end{array}$ & $\begin{array}{l}\text { Time } \\
(\mathrm{sec})\end{array}$ & MRR & $\begin{array}{l}\text { Surface } \\
\text { roughness }\end{array}$ & $\begin{array}{l}\text { Surface } \\
\text { roughness }\end{array}$ \\
\hline & (RPM) & $(\mathrm{mm} / \mathrm{rev})$ & & & & & $(\mathrm{gm} / \mathrm{sec})$ & $\begin{array}{l}\text { (Ra in } \\
\text { micrometer) }\end{array}$ & $\begin{array}{l}\text { (Rz in } \\
\text { micrometer) }\end{array}$ \\
\hline 1 & 200 & 0.15 & 0.2 & 35.37 & 35.11 & 17 & 0.01529 & 1.347 & 6.338 \\
\hline 2 & 200 & 0.25 & 0.4 & 35.36 & 34.33 & 12 & 0.08583 & 1.551 & 6.227 \\
\hline 3 & 300 & 0.25 & 0.2 & 35.35 & 35.11 & 11 & 0.02181 & 0.835 & 4.91 \\
\hline 4 & 300 & 0.15 & 0.4 & 35.38 & 34.17 & 13 & 0.09307 & 1.096 & 4.226 \\
\hline
\end{tabular}


feed and depth of cut were taken $0.2 \mathrm{~mm}$. The cutting time was

Similarly, In the first stage, Inconel-718 was machined by fixing some parameters like the speed of $200 \mathrm{rpm}, 0.15 \mathrm{~mm}$ taken for 18 seconds. The result of MRR is $0.04222 \mathrm{~g} / \mathrm{sec}$ and the surface roughness $\mathrm{Ra}=3.186$ micron and $\mathrm{Rz}=17.130$ micrometre are shown in Table 5.

Table 5. Design matrix table for Inconel-718

\begin{tabular}{|c|c|c|c|c|c|c|c|c|c|}
\hline $\begin{array}{l}\text { Serial } \\
\text { No. }\end{array}$ & Speed & Feed & $\begin{array}{l}\text { Depth } \\
\text { of cut } \\
(\mathrm{mm})\end{array}$ & $\begin{array}{l}\text { Weight before } \\
\text { machining }(\mathrm{gm})\end{array}$ & $\begin{array}{c}\text { Weight after } \\
\text { machining }(\mathrm{gm})\end{array}$ & $\begin{array}{l}\text { Time } \\
(\mathrm{sec})\end{array}$ & MRR & $\begin{array}{c}\text { Surface } \\
\text { roughness }\end{array}$ & $\begin{array}{c}\text { Surface } \\
\text { roughness }\end{array}$ \\
\hline & (RPM) & (mm/rev) & & & & & $(\mathrm{gm} / \mathrm{sec})$ & $\begin{array}{c}\text { ( } \mathrm{Ra} \text { in } \\
\text { micrometer) }\end{array}$ & $\begin{array}{c}\text { ( } \mathrm{Rz} \text { in } \\
\text { micrometer) }\end{array}$ \\
\hline 1 & 200 & 0.15 & 0.2 & 73.87 & 73.11 & 18 & 0.04222 & 3.186 & 17.13 \\
\hline 2 & 200 & 0.25 & 0.4 & 73.81 & 71.07 & 11 & 0.24909 & 4.512 & 13.464 \\
\hline 3 & 300 & 0.25 & 0.2 & 73.78 & 72.93 & 11 & 0.07727 & 1.673 & 8.558 \\
\hline 4 & 300 & 0.15 & 0.4 & 73.85 & 71.34 & 14 & 0.17928 & 1.81 & 11.226 \\
\hline
\end{tabular}

In the second stage, the parameters were changed by 200rpm speed, 0.25 feed rate and depth of cut were taken as $0.4 \mathrm{~mm}$. On this parameter, the time was taken 11 seconds. The MRR was $0.24909 \mathrm{~g} / \mathrm{sec}$ and the surface roughness $\mathrm{Ra}=4.512$ micrometre and $\mathrm{Rz}=13.464$ micrometre.
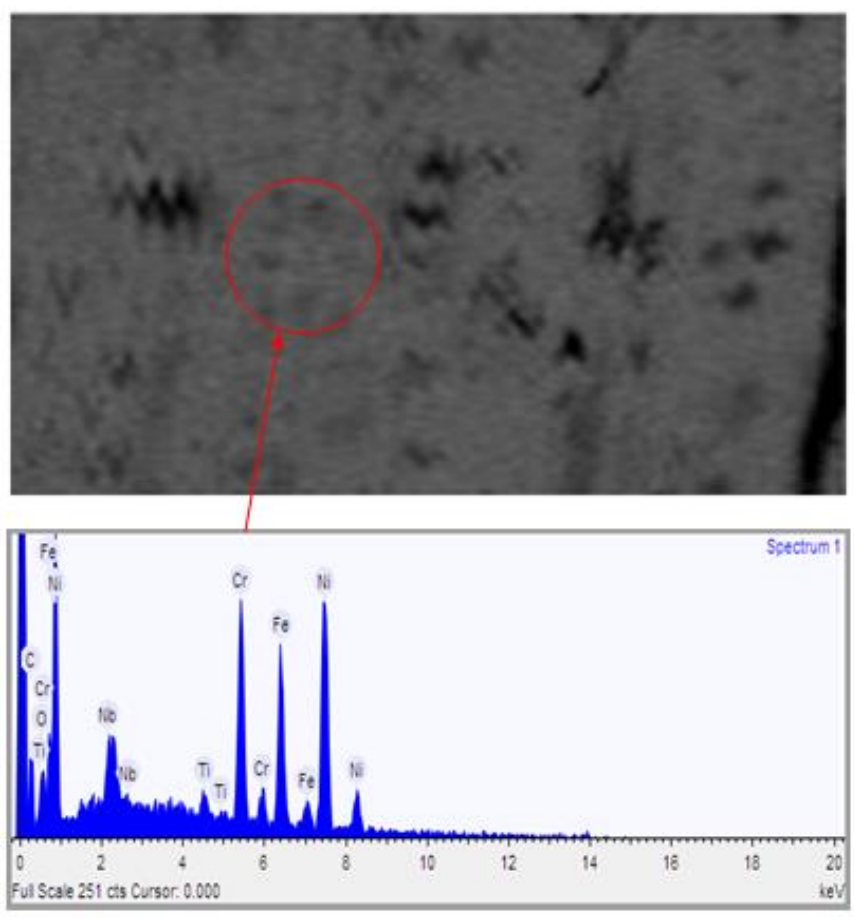

Figure 4. INCONEL-718 SEM Image and EDAX Pattern

On the same parameter, the Inconel-718 was machined. The time cutting was taken for 11 seconds. The MRR was observed $0.07727 \mathrm{~g} / \mathrm{sec}$ and surface roughness $\mathrm{Ra}=1.673$ micrometre and $\mathrm{Rz}=8.55$ micrometre. In the third stage, the parameters were changed by $300 \mathrm{rpm}$ speed, 0.25 feed rate and depth of cut were taken as $0.2 \mathrm{~mm}$. On these parameters, the Inconel718 was operated and the time was taken for 14 seconds. The MRR was $0.07727 \mathrm{~g} / \mathrm{sec}$ and the surface roughness was $\mathrm{Ra}=1.673$ micrometer and $\mathrm{Rz}=8.558$ micrometre. In the fourth stage, the parameters were changed by $300 \mathrm{rpm}$ speed, 0.15 feed rate and depth of cut were taken as $0.4 \mathrm{~mm}$. The MRR was $0.17727 \mathrm{~g} / \mathrm{sec}$ and the surface roughness was $\mathrm{Ra}=1.810$ micrometer and $\mathrm{Rz}=11.216$ micrometre. From the experimental results, it is recorded that if cutting speed increases the cutting forces are decreases. Due to less heat dissipation, the temperature generation is high at high cutting speed. Whereas, the cutting forces increase with an increase in feed rate. The material removal rate of Inconel-718 has decreased by the increment of speed and feed rate. Whereas, it was observed that the surface roughness has significantly decreased. Figure 4 shows the SEM image and Energy Dispersive X-Ray Analysis (EDAX) Pattern of Inconel-718 at speed $200 \mathrm{rpm}, 0.15 \mathrm{~mm}$ feed and $0.2 \mathrm{~mm}$ depth of cut. Surface roughness trends were observed in the SEM test.

\subsection{Machining results of tool steel}

On the same parameters, the tool steel was machined. The total time was taken for 34 seconds. The MRR was recorded $0.11735 \mathrm{~g} / \mathrm{sec}$, surface roughness was $\mathrm{Ra}=1.820$ micrometre and $\mathrm{Rz}=8.094$ micrometre. It was found that the surface roughness increases with the increase in feed rate. Table 6 shows the MRR and surface roughness for tool steel but it decreased when the speed is increased.

Table 6. Design matrix table for Tool steel

\begin{tabular}{|c|c|c|c|c|c|c|c|c|c|}
\hline $\begin{array}{c}\text { Serial } \\
\text { No. }\end{array}$ & Speed & Feed & $\begin{array}{l}\text { Depth of } \\
\text { cut (mm) }\end{array}$ & $\begin{array}{l}\text { Weight before } \\
\text { machining }(\mathrm{gm})\end{array}$ & $\begin{array}{c}\text { Weight after } \\
\text { machining }(\mathrm{gm})\end{array}$ & $\begin{array}{l}\text { Time } \\
(\mathrm{sec})\end{array}$ & MRR & $\begin{array}{c}\text { Surface } \\
\text { roughness }\end{array}$ & $\begin{array}{c}\text { Surface } \\
\text { roughness }\end{array}$ \\
\hline & (RPM) & $(\mathrm{mm} / \mathrm{rev})$ & & & & & $(\mathrm{gm} / \mathrm{sec})$ & $\begin{array}{l}\text { (Ra in } \\
\text { micrometer) }\end{array}$ & $\begin{array}{l}\text { (Rz in } \\
\text { micrometer) }\end{array}$ \\
\hline 1 & 200 & 0.15 & 0.2 & 69.52 & 65.53 & 34 & 0.11735 & 1.82 & 8.094 \\
\hline 2 & 200 & 0.25 & 0.4 & 69.67 & 63.71 & 12 & 0.49666 & 3.329 & 15.612 \\
\hline 3 & 300 & 0.25 & 0.2 & 69.58 & 63.32 & 17 & 0.36823 & 2.492 & 11.498 \\
\hline 4 & 300 & 0.15 & 0.4 & 69.64 & 65.67 & 12 & 0.33083 & 2.081 & 11.183 \\
\hline
\end{tabular}

The machining time was taken for 12 seconds. The MRR was recorded $0.49666 \mathrm{~g} / \mathrm{sec}$ and shown in Table 6 . The surface roughness was recorded $\mathrm{Ra}=3.329$ micrometre and $\mathrm{Rz}=15.612$ micrometer. When the spindle speed increases up to $300 \mathrm{rpm}$ and the tool steel was machined, the machining time was taken for 17 seconds. The MRR was recorded $0.36823 \mathrm{~g} /$ second and surface roughness was $\mathrm{Ra}=2.492$ micrometre and $\mathrm{Rz}=11.498$ micrometre. On the same speed and feed is taken $0.15 \mathrm{~mm} / \mathrm{rev}$ 
the machining time was taken for 12 seconds. The MRR was recorded $0.33083 \mathrm{~g} / \mathrm{sec}$ and surface roughness was $\mathrm{Ra}=2.081$ micrometre and $\mathrm{Rz}=11.183$ micrometer. Figure 5 shows the SEM image and Energy Dispersive X-Ray Analysis (EDAX) Pattern of tool steel at speed $200 \mathrm{rpm}, 0.15 \mathrm{~mm}$ feed and $0.2 \mathrm{~mm}$ depth of cut. Surface roughness trends were observed in the SEM test.

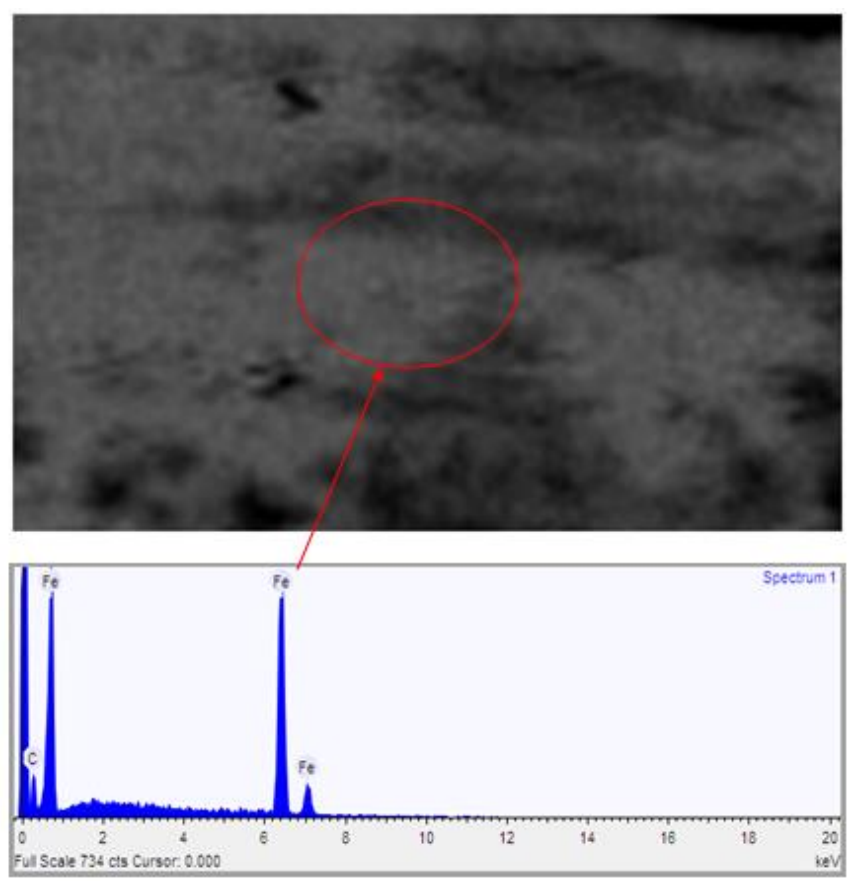

Figure 5. Tool Steel SEM Image and EDAX Pattern

\section{CONCLUSIONS}

From the results generated, it tends to be presumed that since the hardness of titanium alloy is high hence, it is difficult to machine as compare to INCONEL-718 and Tool steel. At $200 \mathrm{rpm}, 0.15$ feed, $0.2 \mathrm{~mm}$ depth of cut MRR and surface roughness of titanium was estimated as $0.01529 \mathrm{~g} / \mathrm{sec}$ and $\mathrm{Ra}=1.347$ micrometre, $\mathrm{Rz}=6.348$ micrometer. For the machining of INCONEL-718, MRR was estimated as 0.04222 $\mathrm{g} / \mathrm{sec}$ and surface roughness $\mathrm{Ra}=0.0422$ micrometre and $\mathrm{Rz}=3.146$ micrometre. For the machining of Tool steel MRR was estimated as $0.11735 \mathrm{~g} / \mathrm{sec}$ and surface roughness $\mathrm{Ra}=$ 1.82 micrometre and $\mathrm{Rz}=8.099$. When the speed increases, the surface roughness of the titanium is increased rapidly as compared to the Inconel-718 and Tool steel. It was observed that the surface roughness of Inconel-718 and tool steel increased by increasing the feed rate and depth of cut. But for Titanium it was decreased. MRR is strictly depended upon speed, feed and depth of cut. However, MRR increases with speed, feed and depth of cut. From the results, it was also noticed that MRR highly increases of Tool steel than Inconel718. SEM results of Ti-6Al-4V, INCONEL-718, and Tool steel showed no cracking within graded regions. It was examined that the surface finish of Ti-6Al-4V is much better than INCONEL-718 and Tool steel even after changing the machining parameters. From the results generated, it tends to be presumed that since the hardness of titanium alloy is high hence, it is difficult to machine as compare to INCONEL-718 and Tool steel. At $200 \mathrm{rpm}, 0.15$ feed, $0.2 \mathrm{~mm}$ depth of cut MRR and surface roughness of titanium was estimated as
$0.01529 \mathrm{~g} / \mathrm{sec} \quad$ and $\mathrm{Ra}=1.347 \quad$ micrometre, $\mathrm{Rz}=6.348$ micrometer. For the machining of INCONEL-718, MRR was estimated as $0.04222 \mathrm{~g} / \mathrm{sec}$ and surface roughness $\mathrm{Ra}=0.0422$ micrometre and $\mathrm{Rz}=3.146$ micrometre, For the machining of Tool steel MRR was estimated as $0.11735 \mathrm{~g} / \mathrm{sec}$ and surface roughness $\mathrm{Ra}=1.82$ micrometre and $\mathrm{Rz}=8.099$. When the speed increases, the surface roughness of the titanium is increased rapidly as compared to the Inconel-718 and Tool steel. It was observed that the surface roughness of Inconel-718 and tool steel increased by increasing the feed rate and depth of cut. But for Titanium it was decreased. MRR is strictly depended upon speed, feed and depth of cut. However, MRR increases with speed, feed and depth of cut. From the results, it was also noticed that MRR highly increases of Tool steel than Inconel-718. SEM results of Ti-6Al-4V, INCONEL718 , and Tool steel showed no cracking within graded regions. It was examined that the surface finish of Ti-6Al-4V is much better than INCONEL-718 and Tool steel even after changing the machining parameters.

\section{REFERENCES}

[1] Fonda, P., Wang, Z., Yamazaki, K., Akutsu, Y. (2008). A fundamental study on Ti-6Al-4V's thermal and electrical properties and their relation to EDM productivity. Journal of Materials Processing Technology, 202(1-3): 583-589. https://doi.org/10.1016/j.jmatprotec.2007.09.060

[2] Ezugwu, E.O., Da Silva, R.B., Bonney, J., Machado, A.R. (2005). Evaluation of the performance of CBN tools when turning $\mathrm{Ti}-6 \mathrm{Al}-4 \mathrm{~V}$ alloy with high pressure coolant supplies. International Journal of Machine Tools and Manufacture, 45(9): 1009-1014. https://doi.org/10.1016/j.ijmachtools.2004.11.027

[3] Sima, M., Özel, T. (2010). Modified material constituent model for serrated chip formation simulation and experiment validation in machining of titanium alloy Ti$6 \mathrm{Al}-4 \mathrm{~V}$. International Journal of Machine Tool and Manufacture, $\quad 50(11)$ : $\quad 943-960$. https://doi.org/10.1016/j.ijmachtools.2010.08.004

[4] Dandekar, C.R., Shin, Y.C., Barnes, J. (2010). Machinability improvement of titanium alloy (Ti-6Al$4 \mathrm{~V})$ via LAM and hybrid machining. International Journal of Machine Tools and Manufacture, 50(2): 174182. https://doi.org/10.1016/j.ijmachtools.2009.10.013

[5] Aramcharoen, A. (2016). Influence of cryogenic cooling on tool wear and chip formation in turning of titanium alloy. Procedia CIRP, 46(1): 83-86. https://doi.org/10.1016/j.procir.2016.03.184

[6] Deiab, I., Raza, S.W., Pervaiz, S. (2014). Analysis of lubrication strategies for sustainable machining during turning of titanium Ti-6Al-4V alloy. Procedia CIRP, 17: 766-771. https://doi.org/10.1016/j.procir.2014.01.112

[7] Ribeiro, M.V., Moreira, M.R.V., Ferreira, J.R. (2003). Optimization of titanium alloy $(6 \mathrm{Al}-4 \mathrm{~V})$ machining. Journal of Materials Processing Technology, 143: 458463. https://doi.org/10.1016/S0924-0136(03)00457-6

[8] Pramanik, A., Littlefair, G. (2015). Machining of titanium alloy (Ti-6Al-4V) - theory to application. Machining Science and Technology, 19(1): 1-49. https://doi.org/10.1080/10910344.2014.991031

[9] Ohkubo, C., Watanabe, I., Ford, J.P., Nakajima, H., Hosoi, T., Okabe, T. (2000). The machinability of cast 
titanium and Ti-6Al-4V. Biomaterials, 21(4): 421-428. https://doi.org/10.1016/S0142-9612(99)00206-9

[10] Lei, S., Liu, W. (2002). High-speed machining of titanium alloys using the driven rotary tool. International Journal of Machine Tools and Manufacture, 42(6): 653661. https://doi.org/10.1016/S0890-6955(02)00012-3

[11] Ahmet, H., Ulas, C. (2007). Electrical discharge machining of titanium alloy (Ti-6Al-4V). Appl Surf Sci, 253: 9007-9016.

[12] Zhuang, K., Zhu, D., Zhang, X., Ding, H. (2014). Notch wear prediction model in turning of Inconel 718 with ceramic tools considering the influence of work hardened layer. Wear, 313(1-2): 63-74. https://doi.org/10.1016/j.wear.2014.02.007

[13] Costes, J.P., Guillet, Y., Poulachon, G., Dessoly, M. (2007). Tool-life and wear mechanisms of CBN tools in machining of Inconel 718. International Journal of Machine Tools and Manufacture, 47(7-8): 1081-1087. https://doi.org/10.1016/j.ijmachtools.2006.09.031

[14] Chen, Y.C., Liao, Y.S. (2003). Study on wear mechanisms in drilling of Inconel 718 superalloy. Journal of Materials Processing Technology, 140(1-3): 269-273. https://doi.org/10.1016/S0924-0136(03)007921

[15] Ezugwu, E.O., Bonney, J., Fadare, D.A., \& Sales, W.F. (2005). Machining of nickel-base, Inconel 718, alloy with ceramic tools under finishing conditions with various coolant supply pressures. Journal of Materials Processing Technology, 162: 609-614. https://doi.org/10.1016/j.jmatprotec.2005.02.144

[16] Rahman, M., Seah, W.K.H., Teo, T.T. (1997). The machinability of Inconel 718. Journal of Materials Processing Technology, 63(1-3): 199-204. https://doi.org/10.1016/S0924-0136(96)02624-6

[17] Kose, E., Kurt, A., Seker, U. (2008). The effects of the feed rate on the cutting tool stresses in machining of Inconel 718. Journal of Materials Processing Technology, 196(1-3): $165-173$ https://doi.org/10.1016/j.jmatprotec.2007.05.019

[18] D’addona, D.M., Raykar, S.J., Narke, M.M. (2017). High speed machining of Inconel 718: tool wear and surface roughness analysis. Procedia CIRP, 62: 269-274. https://doi.org/10.1016/j.procir.2017.03.004

[19] Devillez, A., Le Coz, G., Dominiak, S., Dudzinski, D. (2011). Dry machining of Inconel 718, workpiece surface integrity. Journal of Materials Processing Technology, 211(10): 1590-1598. https://doi.org/10.1016/j.jmatprotec.2011.04.011

[20] Zhou, J., Bushlya, V., Avdovic, P., Ståhl, J.E. (2012). Study of surface quality in high speed turning of Inconel 718 with uncoated and coated CBN tools. The International Journal of Advanced Manufacturing Technology, 58(1-4): 141-151. https://doi.org/10.1007/s00170-011-3374-7

[21] Bosheh, S.S., Mativenga, P.T. (2006). White layer formation in hard turning of $\mathrm{H} 13$ tool steel at high cutting speeds using $\mathrm{CBN}$ tooling. International Journal of Machine Tools and Manufacture, 46(2): 225-233. https://doi.org/10.1016/j.ijmachtools.2005.04.009

[22] Thiele, J.D., Melkote, S.N. (1999). Effect of cutting edge geometry and workpiece hardness on surface generation in the finish hard turning of AISI 52100 steel. Journal of Materials Processing Technology, 94(2-3): 216-226. https://doi.org/10.1016/S0924-0136(99)00111-9

[23] Haron, C.C., Ginting, A., Goh, J.H. (2001). Wear of coated and uncoated carbides in turning tool steel. Journal of Materials Processing Technology, 116(1): 4954. https://doi.org/10.1016/S0924-0136(01)00841-X

[24] Gaitonde, V.N., Karnik, S.R., Figueira, L., Davim, J.P. (2009). Analysis of machinability during hard turning of cold work tool steel (type: AISI D2). Materials and Manufacturing Processes, 24(12): 1373-1382. https://doi.org/10.1080/10426910902997415

[25] Shalaby, M.A., El Hakim, M.A., Abdelhameed, M.M., Krzanowski, J.E., Veldhuis, S.C., Dosbaeva, G.K. (2014). Wear mechanisms of several cutting tool materials in hard turning of high carbon-chromium tool steel. Tribology International, 70: 148-154. https://doi.org/10.1016/j.triboint.2013.10.011 